\title{
Comparison of Copper and Cobalt lons Sorption from Aqueous Solutions on Selected Sorbents
}

\author{
Agnieszka Bożęcka ${ }^{1 *}$, Monika Orlof-Naturalna ${ }^{1}$, Aleksander Korpalski ${ }^{1}$ \\ 1 AGH University of Science and Technology, Faculty of Mining and Geoengineering, al. Mickiewicza 30, \\ 30-059 Krakow, Poland \\ * Corresponding author's e-mail: gala@agh.edu.pl
}

\begin{abstract}
In this paper, the sorption capacity of Norit SX2 activated carbon, ground rice husks and C-160 ion exchange resin in relation to the $\mathrm{Cu}^{2+}$ and $\mathrm{Co}^{2+}$ ions was compared. The studied sorption processes were described using the Langmuir adsorption model. The $\mathrm{C}-160$ ion exchange resin was characterized by the highest affinity for both $\mathrm{Cu}^{2+}$ and $\mathrm{Co}^{2+}$ ions. It was shown that rice husk and active carbon are efficient sorbents in diluted solutions. The copper recovery for activated carbon, ion exchanger and rice husk was high. The efficiency of this process was $98.1 \%$; $92.3 \%$ and $88.9 \%$, respectively. Reducing the volume of acid used for regeneration allowed the solution to be concentrated and facilitated element recovery. Regeneration for cobalt occurred to a lesser extent.
\end{abstract}

Keywords: cooper, cobalt, sorption, Langmuir isotherm

\section{INTRODUCTION}

Nowadays, the human activity generates significant amounts of waste, including wastewater, which pose a significant threat to living organisms. Among the substances emitted into the natural environment, there are also cobalt and copper compounds. Cobalt is an element that occurs in the natural environment mainly in mineral forms such as: arsenics, sulfides, arsenosols, hydrates and oxides (Bielański, 2020). Its presence in the Earth's crust is mainly associated with copper and nickel ores, as well as lead, iron and zinc ores. In trace amounts, cobalt is not harmful to humans. It is a component of vitamin B12 and can be found in most tissues. The toxic effect of this element in relation to living organisms is revealed only at high concentrations. Cobalt is one of the contact allergens. Radioactive cobalt is very dangerous to living organisms. Metallic cobalt dust is classified as a carcinogen. The people working in metallurgy, metalworking, printing houses, ceramic industry (cobalt dyes), at paints production and agriculture are mainly exposed to the influence of cobalt and its compounds. There is also a risk of poisoning for the people living in the vicinity of landfills with waste containing cobalt and industrial emitters (Bożęcka and Sanak-Rydlewska, 2018).

Copper, like cobalt, is also a micronutrient essential for the proper functioning of living organisms, but simultaneously, after exceeding a certain level, it can cause a toxic effect. Its most important task in a body is to participate in oxidation-reduction processes as well as to normalize metabolism and iron transfer. Its deficiency causes a significant reduction in the copper-dependent enzymes and this leads to the inhibition of cell life processes (Ogórek et al., 2017). High concentrations of copper can cause serious toxicological symptoms, as it affects the brain, skin, liver and pancreas (Al-Saydeh et al., 2017).

Copper is a valuable element widely used in many industries. Due to its very good electrical conductivity, it is mainly used in the electrical industry. It is also used in the production of alloys, such as: brass, bronze, alloys with aluminum, manganese and beryllium. The copper compounds are also used in the dyeing industry, for 
production of wood preservatives, bactericides and algicides (Al-Saydeh et al., 2017). For this reason, the concentration of copper compounds in untreated industrial wastewater is usually high. Significant contamination of the environment with copper also occurs near mines and smelters of this metal (Seńczuk, 2017).

The removal of metals including cobalt and copper ions from aqueous solutions, is performed using such methods as: precipitation (Lundström et al., 2016), electrochemical processes (Jack et al., 2014; Li et al., 2017) and membrane processes (Ahmad and Ooi, 2010; Tran et al., 2012), adsorption and ion exchange (Edebali and Pehlivan, 2016; Prakash and Arungalai Vendan, 2016; Shahamirifard et al., 2016; Bożęcka and SanakRydlewska, 2018; Kołodyńska et al., 2017; Al-Saydeh et al., 2017) are commonly used. In recent years, the methods based on sorption with use of biological materials were also proposed. In their case, both: dead organic matter (organic waste) and microorganisms can act as sorbents. Both types of materials are characterized by significant sorption capacity, which is confirmed by numerous scientific studies (Singh and Shukla 2016; Dil et al., 2017; Nischitha et al., 2017; Duru et al., 2019; Kovacova et al., 2019; Al Moharbi et al., 2020).

The choice of a water and wastewater treatment methods always depends on a number of parameters, including: the type and composition of wastewater, as well as the form and concentration of removed pollutants. The effectiveness of the selected method and economic considerations are also important. The interest of the studied elements is constantly increasing, because they belong to the group of valuable metals, which makes the search for additional sources and methods of their recovery extremely important.

In this paper, the sorption capacity of commercial activated carbon, ground rice husks and cation exchanger resin with sulfonic groups was compared. A sorption analysis was performed in a wide range of concentrations, from 10 to $10000 \mathrm{mg} / \mathrm{L}$. The sorption processes were interpreted based on the Langmuir adsorption model. The possibility of regeneration of used materials and copper recovery was also investigated. The results obtained for copper were compared with the results of studies on the sorption and regeneration of cobalt ions (Bożęcka et al., 2018).

\section{MATERIALS AND METHODS}

Activated carbon Norit SX2 (Brenntag AG), rice husks (Oryza sativa L.) and C-160 ion exchange resin (Purolite) were used for the research.

The rice husks were derived from the Italian varieties of brown rice. The preparation of this material consisted of grinding and sieving through a sieve with a diameter of $0.5 \mathrm{~mm}$. The synthetic ion exchange resin was a strongly acidic C-160 cation exchanger with sulfonic groups. Before use, this material was swelled in deionized water for at least 24 hours. Ion exchanger worked in the sodium form.

Sorption was performed in $250 \mathrm{ml}$ Erlenmeyer flasks $2 \mathrm{~g}$ of sorbents and $200 \mathrm{ml}$ of copper solutions with the initial concentrations in the range of $10-10000 \mathrm{mg} / \mathrm{L}$ were used for research. The solutions were prepared from hydrated copper(II) nitrate(V), $\left[\mathrm{Cu}\left(\mathrm{NO}_{3}\right)_{2} \cdot 3 \mathrm{H}_{2} \mathrm{O}\right]$, (made by ACROS ORGANICS).

The flasks prepared in this way were shaken for 60 minutes using a laboratory shaker with constant speed equal to $200 \mathrm{rpm}$. The length of process was determined based on the previous research. It was assumed that 60 minutes is the time to achieve sorption equilibrium. The initial $\mathrm{pH}$ of the tested solutions was 4.0. Its value was adjusted with nitric (V) acid. The conditions of the sorption processes for the $\mathrm{Cu}^{2+}$ ions were identical to those for the $\mathrm{Co}^{2+}$ ions (Bożęcka et al., 2018).

The regeneration of materials was carried out with $50 \mathrm{ml}$ of a $10 \%$ hydrochloric acid solution. For this purpose, the sorbents used in the process of removing the $\mathrm{Cu}^{2+}$ ions from the solutions with the highest tested concentration equal to $10000 \mathrm{mg} / \mathrm{L}$, were implemented. The reagent selection and regeneration conditions were dictated by the recommendations of the ion exchanger manufacturer (Purolite, 2020). Regeneration time was 60 minutes.

The content of the $\mathrm{Cu}^{2+}$ ions in the tested solutions was determined using two methods: cuprizone and ammonia with use of a UV-VIS spectrophotometer Cadas 200 Dr. Lange. The analysis with cuprizone were carried out in an ammoniacitrate medium at $\mathrm{pH}$ in range 8.0-9.5. The absorbance of copper solutions was measured at a wavelength of $600 \mathrm{~nm}$ (cuprizone method) and $608 \mathrm{~nm}$ (ammonia method). 
The sorption capacity was calculated using Eq. (1):

$$
q_{e}=\frac{V\left(c_{0}-c_{e}\right)}{m}
$$

where: $q_{e}$ is the amount of the adsorbed $\mathrm{Cu}^{2+}$ ions per gram of ion exchanger in equilibrium, $\mathrm{mg} / \mathrm{g}$,

$V$ - is the volume of the solution, $\mathrm{L}$,

$c_{o}$ and $c_{\mathrm{e}}$ are the initial and equilibrium concentrations of the $\mathrm{Cu}^{2+}$ ions in the studied solution, $\mathrm{mg} / \mathrm{L}$,

$m$ is the quantity of dry mass of the ion exchanger, $g$.

The Langmuir adsorption model was used to describe studied sorption processes. This theory assumes that the surface of adsorbent is homogeneous and has a fixed number of active sites. Localized adsorption takes place. A molecule adsorbed on the surface cannot move freely. Lateral interactions are irrelevant. Monolayer adsorption takes place, meaning that each active site is occupied by only one molecule (Bansal and Goyal, 2009). The Langmuir model is described by Eq. (2):

$$
q_{e}=\frac{q_{\max } \cdot b \cdot c_{e}}{\left(1+b \cdot c_{e}\right)}
$$

where: $q_{e}$ is the amount of adsorbed $\mathrm{Cu}^{2+}$ ions per gram of ion exchanger in equilibrium, $\mathrm{mg} / \mathrm{g}$,

$c_{e}-$ the equilibrium concentrations of the adsorbate in the solution, $\mathrm{mg} / \mathrm{L}$,

$q_{\max }-$ maximum adsorbent capacity, $\mathrm{mg} / \mathrm{g}, b-$ affinity between the adsorbent and removed ions, $\mathrm{L} / \mathrm{mg}$.

The Langmuir $b$ and $q_{\max }$ coefficients were determined using the linear form of the Langmuir isotherm equation Eq. (3):

$$
\frac{1}{q_{e}}=\frac{1}{q_{\max } \cdot b} \cdot\left(\frac{1}{c_{e}}+b\right)
$$

\section{RESULTS AND DISCUSSION}

The results of the sorption studies in the solutions with an initial $\mathrm{pH}$ equal 4.0 are shown in Figure 1 and Table 1.
Activated carbon was characterized by the best sorption capacity in $10 \mathrm{mg} / \mathrm{L}$ and $25 \mathrm{mg} / \mathrm{L}$ solutions (Fig. 1a). The degree of the $\mathrm{Cu}^{2+}$ ion separation for these systems was $100 \%$. It was observed that with increasing concentration, sorption decreased gradually, reaching the value of about $8 \%$ at $750 \mathrm{mg} / \mathrm{L}$. The sorption efficiency for next concentrations also showed a downward trend, but with a gentler course. On this basis, it was concluded that Norit SX2 activated carbon was an effective sorbent only in diluted systems.

Rice husk, like activated carbon, had good sorption results for diluted solutions (Fig. 1b). However, the sorption efficiency was lower than for activated carbon practically for the entire concentration range. The effectiveness of rice husk as a sorbent could be limited by the presence of numerous areas on its surface covered with "silica shell” (Bożęcka et al., 2018). The performed surface studies did not show the removed ions in these areas, which confirms the lack of sorption.

The C-160 ion exchanger was an effective sorbent. This resin in the solutions with concentrations up to $250 \mathrm{mg} / \mathrm{L}$ was characterized by over $98 \% \mathrm{Cu}^{2+}$ ion removal. For higher concentrations, satisfactory results were obtained up to $1000 \mathrm{mg} / \mathrm{L}$, for which the degree of purification was over $70 \%$. Over $1000 \mathrm{mg} / \mathrm{L}$, the ion exchanger efficiency decreased, reaching the lowest value of about $9 \%$ for a solution with a concentration of $10000 \mathrm{mg} / \mathrm{L}$ (Fig. 1c).

Comparing the results obtained for the copper ions with the results of the cobalt ion sorption studies (Fig. 1, Table 1), it was found that for the ion exchanger the efficiency of process was similar in the entire concentration range. In diluted systems, activated carbon and rice husk removed the $\mathrm{Cu}^{2+}$ ions more effectively. Sorption was much higher than for the $\mathrm{Co}^{2+}$ ions. In more concentrated solutions, a slightly higher efficiency of the $\mathrm{Co}^{2+}$ removal was observed. The course of sorption processes for the range of higher concentrations was practically constant. However, for the $\mathrm{Cu}^{2+}$ ions, a slight downward trend was visible with increasing concentration (Fig. 1).

The obtained study results were interpreted in accordance to the Langmuir equation and are shown in Figure 2. The values of $q_{\max }$ and $b$ coefficients were shown in Table 1.

It was found that the sorption capacity of the studied materials gradually increased. This increase was the fastest in the case of the C-160 ion 


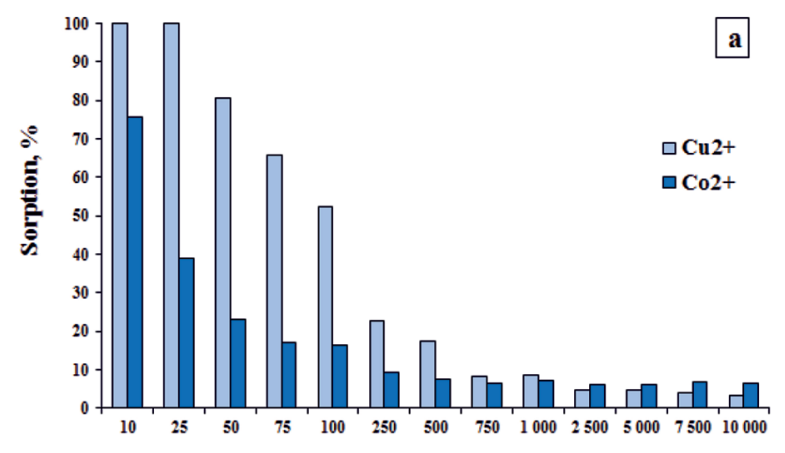

Initial concentrations, $\mathrm{mg} / \mathrm{L}$

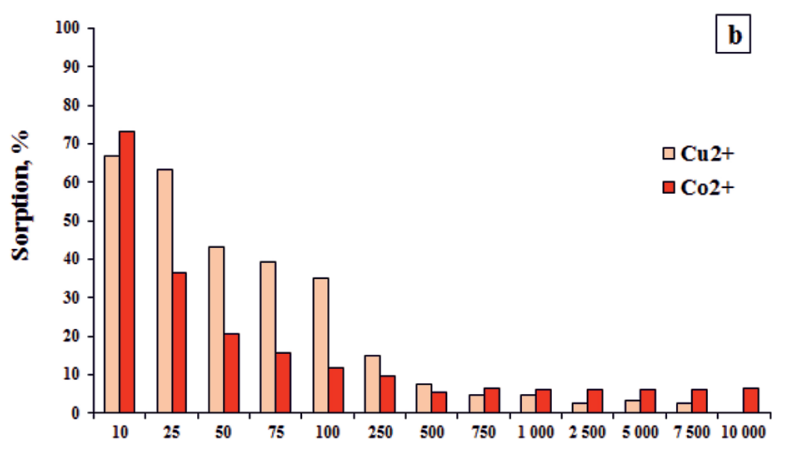

Initial concentrations, $\mathrm{mg} / \mathbf{L}$

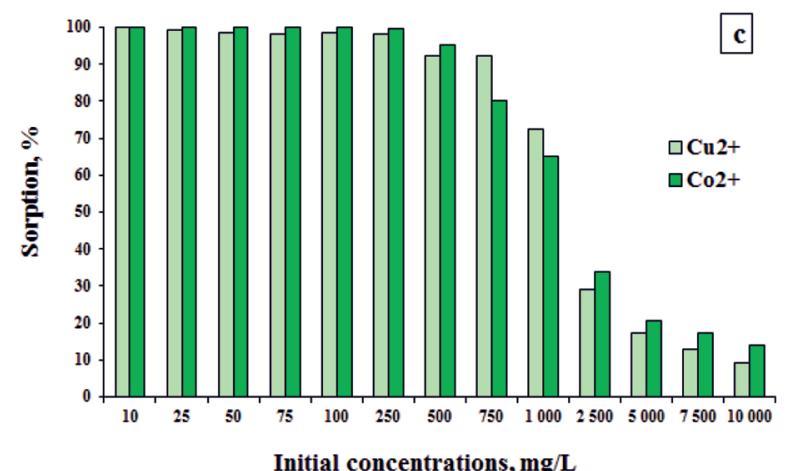

Figure 1. Comparison of the $\mathrm{Cu}^{2+}$ and $\mathrm{Co}^{2+}$ ions sorption from water solutions with an initial $\mathrm{pH}$ equal 4.0 by using Norit SX2 activated carbon (a), milled rice husk (b) and C-160 ion exchange resin (c)

exchanger. The calculated values of maximum sorption capacity for the $\mathrm{Cu}^{2+}$ ions characterized by the $q_{\max }$ coefficient of the Langmuir isotherm were different. The highest value of this parameter was obtained for ion exchanger $(104.3 \mathrm{mg} / \mathrm{g})$. In the case of activated carbon and rice husk, it amounted to $41.1 \mathrm{mg} / \mathrm{g}$ and $35.1 \mathrm{mg} / \mathrm{g}$, respectively (Table 2).
Next, the parameter $b$ of the Langmuir isotherm, which allows determining the affinity of a sorbent for the removed ions, was also the highest for ion exchanger $(0.0013 \mathrm{~L} / \mathrm{mg})$. The other materials showed a much lower affinity $(0.00032 \mathrm{~L} / \mathrm{mg}$ for activated carbon and $0.00014 \mathrm{~L} / \mathrm{mg}$ for rice husk). In the case of these sorbents, it was concluded

Table 1. Removal of the $\mathrm{Cu}^{2+}$ and $\mathrm{Co}^{2+}$ ions from water solutions with an initial pH equal 4.0 by using Norit SX2 activated carbon, milled rice husk and C-160 ion exchange resin

\begin{tabular}{|c|c|c|c|c|c|c|}
\hline \multirow{2}{*}{$\begin{array}{c}\text { Initial concentrations, } \\
\mathrm{mg} / \mathrm{L}\end{array}$} & \multicolumn{3}{|c}{$\begin{array}{c}\text { Sorption of } \mathrm{Cu}^{2+} \text { ions, \% } \\
\text { (Present study) }\end{array}$} & \multicolumn{3}{c|}{$\begin{array}{c}\text { Sorption of Co }{ }^{2+} \text { ions, \% } \\
\text { (Bożęcka et al., 2018) }\end{array}$} \\
\cline { 2 - 7 } & Norit SX2 & Rice husk & C-160 & Norit SX2 & Rice husk & C-160 \\
\hline 10 & 100.0 & 66.7 & 100.0 & 75.8 & 73.1 & 100.0 \\
\hline 25 & 100.0 & 63.2 & 99.2 & 38.9 & 36.6 & 100.0 \\
\hline 50 & 80.6 & 43.0 & 98.4 & 23.2 & 20.5 & 100.0 \\
\hline 75 & 65.6 & 39.4 & 98.1 & 17.0 & 15.6 & 100.0 \\
\hline 100 & 52.2 & 35.1 & 98.4 & 16.2 & 11.9 & 100.0 \\
\hline 250 & 22.7 & 15.1 & 98.3 & 9.3 & 9.3 & 99.4 \\
\hline 500 & 17.5 & 7.6 & 92.2 & 7.4 & 5.1 & 95.4 \\
\hline 750 & 8.1 & 4.7 & 92.3 & 6.4 & 6.4 & 80.1 \\
\hline 1000 & 8.4 & 4.7 & 72.3 & 7.1 & 6.0 & 65.1 \\
\hline 2500 & 4.5 & 4.5 & 28.9 & 6.0 & 6.0 & 33.7 \\
\hline 5000 & 4.7 & 2.5 & 17.3 & 6.2 & 6.2 & 20.5 \\
\hline 7500 & 3.8 & 3.3 & 12.9 & 6.8 & 6.1 & 17.4 \\
\hline 10000 & 3.1 & 2.6 & 9.4 & 6.5 & 6.4 & 14.1 \\
\hline
\end{tabular}



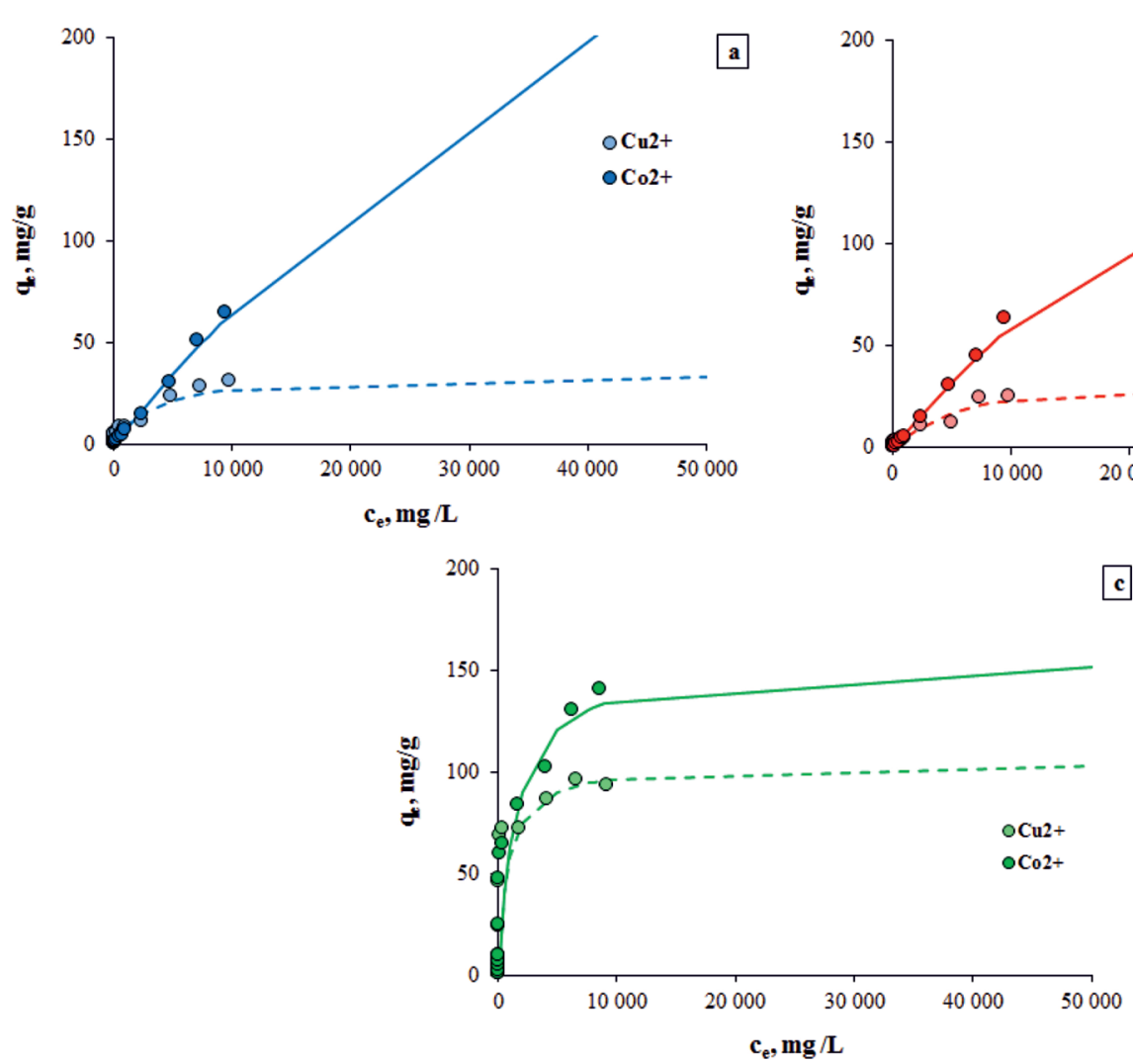

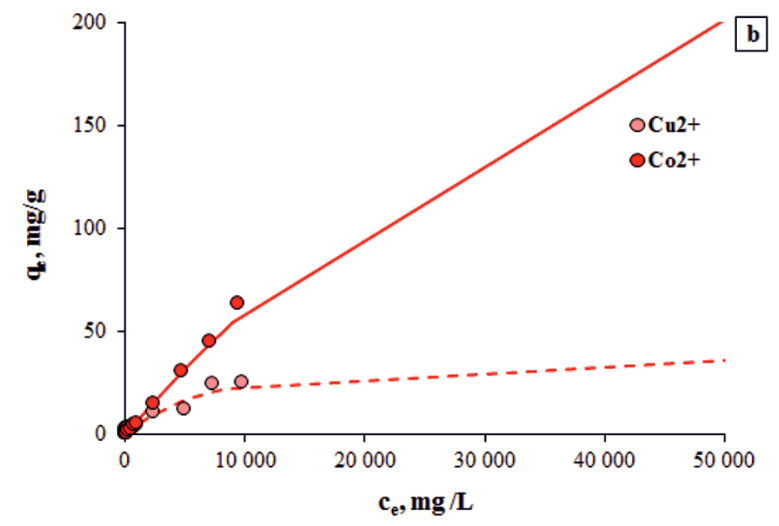

c

Figure 2. Comparison of the Langmuir isotherms for the $\mathrm{Cu}^{2+}$ and $\mathrm{Co}^{2+}$ ions sorption on Norit $\mathrm{SX} 2$ activated carbon (a), milled rice husk (b) and C-160 ion exchange resin (c) in solutions with an initial pH equal 4.0

that their surface should be activated in order to create the active centres capable of binding the $\mathrm{Cu}^{2+}$ ions.

The maximum sorption capacities determined for the studied materials in the $\mathrm{Co}^{2+}$ ions sorption process were higher than for the $\mathrm{Cu}^{2+}$ ions (Table 2). However, their affinity for cobalt was lower than for copper. In the case of ion exchanger, the differences were small, but for rice husk and activated carbon, they were significant.

The regeneration results were shown in Figure 3 and Table 3.

Among all studied sorbents, the highest efficiency of the $\mathrm{Cu}^{2+}$ ion desorption process by using $50 \mathrm{~mL}$ of a $10 \% \mathrm{HCl}$ solution, equal to $98.1 \%$, was obtained for activated carbon.
Copper recovery after regeneration for the C-160 ion exchanger and rice husk was also high. The regeneration efficiency for these materials was $92.3 \%$ and $88.9 \%$, respectively. This high ability to regenerate is undoubtedly an advantage of the materials used. Additionally, reducing volume of $10 \% \mathrm{HCl}$ to $50 \mathrm{~mL}$ compared to the volume of the solution used in the sorption process $(200 \mathrm{~mL})$, allowed the concentration of the solution and facilitated the recovery of copper.

In the case of cobalt, the used ion exchanger regenerated more effectively than activated carbon and rice husk. The desorption efficiency process was $58.1 \%$. The cobalt recovery for activated carbon and rice husk was much lower and amounted to $36.1 \%$ and $28.1 \%$, respectively.

Table 2. Langmuir isotherm coefficients for the $\mathrm{Cu}^{2+}$ and $\mathrm{Co}^{2+}$ ions sorption on Norit $\mathrm{SX} 2$ activated carbon, milled rice husk and $\mathrm{C}-160$ ion exchange resin in solutions with an initial $\mathrm{pH}$ equal 4.0

\begin{tabular}{|c|c|c|c|c|c|c|}
\hline \multirow{2}{*}{ Studied material } & \multicolumn{3}{|c|}{$\begin{array}{c}\mathrm{Cu}^{2+} \\
\text { (Present study) }\end{array}$} & \multicolumn{3}{|c|}{$\begin{array}{c}\mathrm{Co}^{2+} \\
\text { (Bożęcka et al., 2018) }\end{array}$} \\
\hline & $\begin{array}{l}q_{\max } \\
\mathrm{mg} / \mathrm{g}\end{array}$ & $\begin{array}{c}b \\
\mathrm{~L} / \mathrm{mg}\end{array}$ & $R$ & $\begin{array}{l}q_{\max } \\
\mathrm{mg} / \mathrm{g}\end{array}$ & $\begin{array}{c}b \\
\mathrm{~L} / \mathrm{mg}\end{array}$ & $R$ \\
\hline Norit SX2 & 35.1 & 0.00032 & 0.9432 & 765.3 & 0.000009 & 0.9967 \\
\hline Rice husk & 41.1 & 0.00014 & 0.9848 & 494.2 & 0.000014 & 0.9982 \\
\hline C-160 & 104.3 & 0.0013 & 0.9842 & 155.6 & 0.00068 & 0.9541 \\
\hline
\end{tabular}




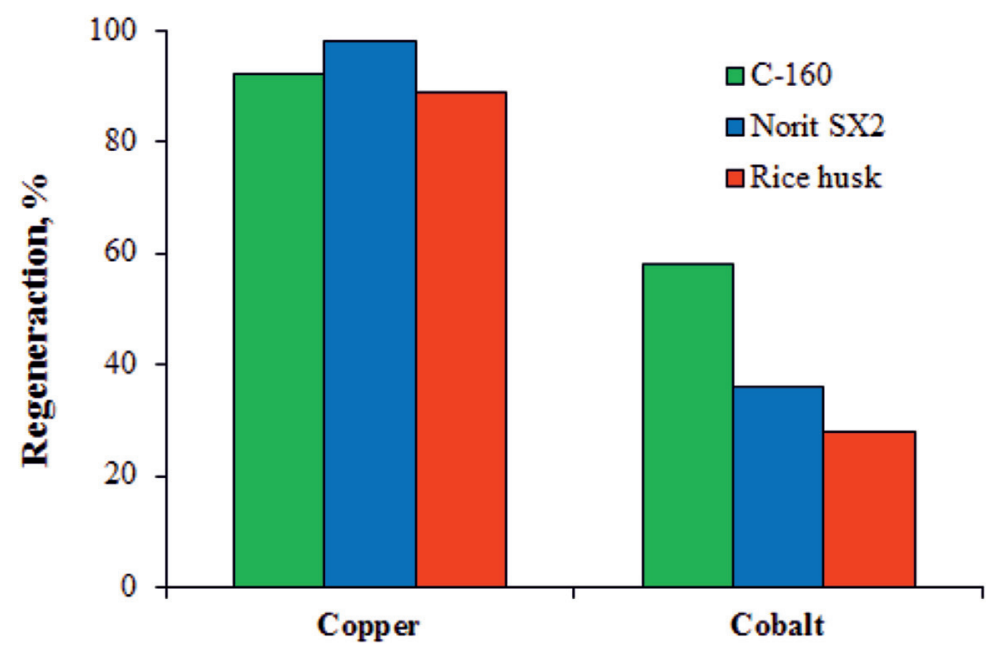

Figure 3. Regeneration of the studied materials with use of a $10 \% \mathrm{HCl}$ solution

Table 3. Desorption of the $\mathrm{Cu}^{2+}$ and $\mathrm{Co}^{2+}$ ions from water solutions with pH equal 4.0 by using Norit SX2 activated carbon, milled rice husk and $\mathrm{C}-160$ ion exchange resin

\begin{tabular}{|c|c|c|c|c|c|}
\hline \multicolumn{3}{|c|}{$\begin{array}{c}\text { Desorption of } \mathrm{Cu}^{2+} \text { ions, \% } \\
\text { (Present study) }\end{array}$} & \multicolumn{3}{c|}{$\begin{array}{c}\text { Desorption of } \mathrm{Co}^{2+} \text { ions, \% } \\
\text { (Bożęcka et al., 2018) }\end{array}$} \\
\hline C-160 & Norit SX2 & Rice husk & C-160 & Norit SX2 & Rice husk \\
\hline 92.3 & 98.1 & 88.9 & 58.1 & 36.1 & 28.1 \\
\hline
\end{tabular}

From the comparison of results, it can be concluded that the regeneration process of studied materials was much more effective for copper.

\section{CONCLUSION}

On the basis of the conducted studies, the following conclusions can be made:

1. The C-160 ion exchanger was the most effective sorbent for the $\mathrm{Cu}^{2+}$ and $\mathrm{Co}^{2+}$ ions in the entire concentration range. For rice husk and activated carbon, satisfactory results were obtained in diluted systems, for which the sorption efficiency of the $\mathrm{Cu}^{2+}$ ions was much higher than in the case of the $\mathrm{Co}^{2+}$ ions. Higher efficiency in removing the $\mathrm{Co}^{2+}$ ions was observed in more concentrated solutions.

2. For copper ions, the highest value of the maximum sorption capacity was obtained for the C-160 ion exchanger $(104.3 \mathrm{mg} / \mathrm{g})$. This sorbent also showed the highest affinity $(0.0013 \mathrm{~L} / \mathrm{mg})$, which confirms its efficiency in removing the studied ions from aqueous solutions. The maximum sorption capacities determined for the $\mathrm{Co}^{2+}$ ions were higher. However, the affinity of used materials for these ions was lower.
3. The highest efficiency of the $\mathrm{Cu}^{2+}$ ions desorption process, equal to $98.1 \%$, was obtained for activated carbon. The copper recovery for C-160 ion exchanger and rice husk was also high. The process efficiencies were $92.3 \%$ and $88.9 \%$, respectively. Reducing the volume of acid used for regeneration, allowed concentrating the solution and facilitated metal recovery. For cobalt, the studied materials regeneration occurred to a much lesser extent, equal to $58.1 \%$ (C-160 ion exchanger), $36.1 \%$ (activated carbon) and $28.1 \%$ (rice husk).

4. Natural sorbents, such as rice husk, can effectively replace synthetic materials in the removal of inorganic contaminants from water. They are cheap and widely available, and their natural sorption capacity can be additionally increased by surface modification with chemical or physical methods.

\section{REFERENCES}

1. Ahmad A.L., Ooi B.S. 2010. A study on acid reclamation and copper recovery using low pressure nanofiltration membrane. Chemical Engineering Journal, 156, 257-263.

2. Al Moharbi S.S., Devi M.G., Sangeetha B.M., Jahan S. 2020. Studies on the removal of copper ions from 
industrial effluent by Azadirachta indica powder. Applied Water Science, 10 (23), 1-10.

3. Al-Saydeh S.A., El-Naasa M.H., Zaidib S.J. 2017. Copper removal from industrial wastewater: A comprehensive review. Journal of Industrial and Engineering Chemistry, 56, 35-44.

4. Bansal R.C., Goyal M. 2009. Adsorption on activated carbon. Scientific Publishers WNT, Warsaw (in Polish).

5. Bielański A. 2020. Basics of inorganic chemistry. Scientific Publishers PWN, Warsaw (in Polish).

6. Bożęcka A., Sanak-Rydlewska S. 2018. The use of ion exchangers for removing cobalt and nickel ions from water solutions. Archives of Mining Sciences, 63(3), 633-646.

7. Bożęcka A., Surdek A., Bożęcki P. 2018. Assessment of suitability of selected sorbents for removal of $\mathrm{Co} 2+$ ions from aqueous solutions. Przemysl Chemiczny, 97(9), 1565-1568 (in Polish).

8. Dil E.A., Ghaedi M., Ghezelbash G.R., Asfaram A., Purkait M.K. 2017. Highly efficient simultaneous biosorption of $\mathrm{Hg} 2+, \mathrm{Pb} 2+$ and $\mathrm{Cu} 2+$ by Live yeast Yarrowia lipolytica 70562 following response surface methodology optimization: Kinetic and isotherm study. Journal of Industrial and Engineering Chemistry, 48, 162-172.

9. Duru, C.E., Duru, I.A., Ogbonna, C.E., Enedoh, M.C., Emele, P. 2019. Adsorption of copper ions from aqueous solution onto natural and pretreated maize husk: adsorption efficiency and kinetic studies. Journal of Chemical Society of Nigeria, 44(5), 798-803.

10. Edebali S., Pehlivan E. 2016. Evaluation of chelate and cation exchange resins to remove copper ions. Powder Technology, 301, 520-525.

11. Jack F., Bostock J., Tito D., Harrison B., Brosnan J. 2014. Electrocoagulation for the removal of copper from distillery waste streams. Journal of the Institute of Brewing, 120, 60-64.

12. Catalog card Purolite C-160 http://www.purolite. $\mathrm{com} /$ product/c160, 10.07.2020.

13. Kołodyńska D., Krukowska-Ba J., KazmierczakRazna J., Pietrzak R. 2017. Uptake of heavy metal ions from aqueous solutions by sorbents obtained from the spent ion exchange resins. Microporous and Mesoporous Materials, 244, 127-136.

14. Kovacova Z., Demcak S., Balintova M. 2019. Removal of copper, zinc and iron from water solutions by spruce sawdust adsorption. Economics and Environment, 3, 64-74.

15. Li J., Wang X., Wang H., Wang S., Hayat T., Alsaedi A., Wang X. 2017. Functionalization of biomass carbonaceous aerogels and their application as electrode materials for electro-enhanced recovery of metal ions. Environmental Science: Nano, 4, 1114-1123.

16. Lundström M., Liipo J, Taskinen P., Aromaa J. 2016. Copper precipitation during leaching of various copper sulfide concentrates with cupric chloride in acidic solutions. Hydrometallurgy, 166, 136-142.

17. Nischitha, S. Y., Karpagam, J., Parimala, C. 2017. Adsorption studies on copper removal from industrial sludge. International Journal of Engineering Research and Modern Education, Special Issue, 167-170.

18. Ogórek M., Gąsior Ł, Pierzchała O., Daszkiewicz R., Lenartowicz M. 2017. Role of copper in the process of spermatogenesis. Postepy Higieny i Medycyny Doswiadczalnej, 71, 662-680 (in Polish).

19. Prakash N., Arungalai Vendan S. 2016. Biodegradable polymer based ternary blends for removal of trace metals from simulated industrial wastewater. International Journal of Biological Macromolecules, 83, 198-208.

20. Seńczuk W. red. 2017. Contemporary toxicology, Medical Publisher PZWL, Warsaw (in Polish).

21. Shahamirifard S.A.R., Ghaedi M., Rahimi M.R., Hajati S., Montazerozohori M., Soylak M. 2016. Simultaneous extraction and preconcentration of $\mathrm{Cu} 2+, \mathrm{Ni} 2+$ and $\mathrm{Zn} 2+$ ions using Ag nanoparticleloaded activated carbon: Response surface methodology. Advanced Powder Technology, 27, 426-435.

22. Singh S.A., Shukla S.R. 2016. Adsorptive removal of cobalt ions on raw and alkali-treated lemon peels. International Journal of Environmental Science And Technology, 13, 165-178.

23. Tran A.T.K., Zhang Y., Jullok N., Meesschaert B., Pinoy L., Van der Bruggen B. 2012. RO concentrate treatment by a hybrid system consisting of a pellet reactor and electrodialysis. Chemical Engineering Science, 79, 228-238. 